\title{
The Voluntary Agencies
}

\section{LEPRA's Contribution to the World-wide Campaign Against Leprosy}

\author{
G. F. HARRIS
}

Director, L.EPR A, 50 Fitzroy Street, L.ondon WIP 6 Al.

\begin{abstract}
LEPRA, the successor to the British Empire Leprosy Relief Association (BELRA) which was founded in 1924, is now a world-wide organization. It works towards its objective, the control of leprosy, by running control schemes, supporting government and other agencies running similar schemes, encouraging and supporting leprosy research, and fostering the early diagnosis and regular treatment of young patients. The expenditure of money raised mainly in the United Kingdom is controlled by an Executive Committee; $£ 286,600$ was raised in 1972 .
\end{abstract}

The British Empire Leprosy Relief Association (BELRA) was set up in 1924 with the object of ridding the Empire of leprosy. With the changing circumstances of the world surrounding a growing organization it was decided in 1967, that the Association's geographical boundaries should no longer be limited to the Empire and that the Association should be known as LEPRA.

The Association's object today is still the eradication of leprosy and LEPRA works towards its objective by employing what are currently considered to be the most effective methods. The Association, honoured by Her Majesty The Queen as its Patron. is managed by an Executive Committee, which is advised from time to time by LEPRA's Medical Committee. Funds are raised. mainly through small groups in the United Kingdom, from legacies, Press advertising etc., and in 1972 amounted to $£ 286,600$.

LEPRA uses its funds in operating its own Control Scheme in Malawi, participating in joint schemes in Sierra Leone, Zambia and elsewhere, running a special scheme for children, and supporting effective leprosy work by governments and by other voluntary organizations. LEPRA also supports research. especially at Oxford University, and encourages medical students to become interested in leprosy by sponsoring essay competitions, by sending selected students to work in Malawi, and by financing an annual lecture, the Clayton Memorial Lecture. LEPRA publishes Leprosy Review and has joined with other organizations in issuing booklets on various aspects of leprosy. In an effort to extend the knowledge of leprosy, LEPRA has arranged to make a new film which will summarize existing information on the subject and will be appropriate for showing to medical and lay audiences. 


\section{Malawi Control Project}

LEPRA decided in the early 1960's that the then widely held idea that leprosy can be eradicated from a defined area should be demonstrated. Accordingly, an area of 2000 square miles with a population of 1.3 million was selected near Blantyre in Malawi. Treatment was to be mainly domiciliary, but a small hospital unit with 36 beds was included in the LEPRA block which catered for administration, training, record keeping and laboratory work. The block was situated in the grounds of a general hospital as a move towards the integration of leprosy treatment with other medical services.

The project was planned to run for 10 years, but already af ter 7 years there are indications of success, for the number of new cases of leprosy registered each month has fallen from over 350 to under 50, and all the new cases are early ones. At the end of 1975 the patients remaining will be able to obtain treatment from static government clinics. Two trained Leprosy Assistants will, however, be retained in the area to ensure that adequate supervision and treatment are maintained in an area where leprosy treatment has been fully integrated with general rural medicine. Detailed records of 12,500 patients are currently being coded so that they can be analysed by computer and thus provide valuable information.

The Government of Malawi has shown its confidence in LEPRA by inviting the Association, through its Director in Malawi, Dr David Molesworth, to become responsible for leprosy control throughout the whole country. This is now being planned on a progressive basis, another control project being started in the North working from an existing government hospital, and a pilot leprosy/tuberculosis control project started in the Centre, based on Lilongwe, the new capital of Malawi. This project, financed by the German Leprosy Relief Association (DAHW), is being advised by the World Health Organization, which has a deep interest in such work. Initially, a population of some 900,000 will be included in the pilot project.

In the South, outside the LEPRA Control Project area, the leprosy work undertaken by UMCA, the Seventh Day Adventists, and the Canadian Sisters of Wisdom is all being co-ordinated by LEPRA on behalf of the Malawian Government. In 1972 LEPRA spent $£ 57,800$ in Malawi.

\section{Sierra Leone}

For 15 years LEPRA has maintained lay workers in Sierra Leone. Recently, leprosy control in that country has been extended and there is a major nation-wide control scheme now in operation under the direction of Fr Rocco Serra. until recently Director of the Catholic Relief Service in Sierra Leone. LEPRA provided four experienced field workers and $£ 27.000$ in 1972. The scheme is also supported with staff and funds by the Government, the German Leprosy Relief Association (DAHW), the Seventh Day Adventists and, in the past, has received financial assistance from the Catholic Relief Service. OXFAM, CAFOD, Fame Pereo, and Friends of Leprosy Patients in Italy and the USA.

\section{Zambia}

Following the success of the Malawi Project, LEPRA was approached by the Government of Zambia to assist with out-patient control in that country. A very 
successful out-patient control scheme was set up in the Eastern Region and run for 2 years by LEPRA, and is now run by the Government. A further scheme was introduced in the Luapula Valley with equal success. During 1972 LEPRA provided an experienced lay worker and contributed $£ 5600$ towards leprosy control in Zambia.

Among other countries which have benefited from LEPRA's support during 1972 were the following.

\section{India}

Most of the money given by LEPRA to voluntary agencies in India was in respect of children, but $£ 4000$ were provided to cover the salaries of local para-medical workers and for the provision of deep wells at one big settlement.

\section{Nigeria}

Grants of $£ 10,500$ were made towards the purchase of transport (including canoes), training, and the running expenses of various control schemes. Dr Wheatley concluded his very exacting task of being Leprosy Adviser to the East Central State and helping to re-establish leprosy control in the war torn area. Chief Lakin has been building up a modern self-supporting agricultural unit to absorb those former patients at Oji River and Uzuakoli who are the legacy of the outdated institutionalized methods of leprosy treatment.

\section{Uganda}

Two LEPRA workers have been stationed at Kumi, one in charge of out-patient control working very closely with local government personnel, and the other in charge of one of the only two leprosy training schools in the country. Grants of $£ 2500$ were made elsewhere in Uganda during 1972.

\section{Peru}

Following protracted negotiations after Dr Colin McDougall's report on the needs of Peru from the leprosy aspect, LEPRA financed the training of a Peruvian in Mexico and supplied some basic equipment. It is hoped that up-to-date methods of leprosy treatment will gradually emerge from this small but practical contribution to the leprosy problem facing Peru.

\section{Children}

LEPRA considers the early diagnosis and treatment of child sufferers from leprosy of paramount importance. Accordingly, under its Children's Fund, annual per capita grants are given following receipt of the patient's name. age. sex and the type of leprosy from which the child is suffering, supported by a medical certificate to the effect that the child needs, and is receiving, either domiciliary or in-patient treatment. The per capita grant is small, but 20,112 children benefited in 1972 at a cost of $£ 62,000$. Indian settlements received $£ 30,000$ of this sum, the balance going to 11 other countries ranging from Colombia to Ethopia. 


\title{
Research
}

LEPRA is all the time supporting and encouraging research in the hope that better methods of detection, quicker acting drugs, and eventually a prophylactic will be found so that leprosy will at last be eradicated.

\section{Conclusion}

The World Health Organization has estimated that within the next 5 years there will be 1 million more people suffering from leprosy. LEPRA is therefore far from achieving its objective. While adequate drugs are available to cure the majority of cases, the main problem is one of administration, politics, and the availability of suitable reliable personnel to work in the field.

Some countries are reluctant to receive expatriates when they already have an unemployment problem; others have no facilities (such as housing) to offer. LEPRA sees a greater hope of success in controlling leprosy, thus preventing future generations from suffering from the disease, than in the rehabilitation of individual patients. It therefore concentrates its efforts overseas, apart from its children's work, on working in areas in which it is well received and supported by the local government so that it can achieve its objective in certain limited areas. Ideally, control projects should be set up and run for a few years during which time the local health staff should be trained to diagnose and treat leprosy so that expatriates can be gradually withdrawn, and once the leprosy problem has been reduced to controllable dimensions it should be integrated with the local health service.

\section{The Leprosy Mission- A Crucial Dimension of Service}

\author{
A. D. ASKEW
}

Deputy International General Secretary, 50 Portland Place, London W.1.

A hundred years ago there took place three apparently unrelated, widely separated, events which were to be of considerable significance in widening the horizons of the world of leprosy. In Europe, Armauer Hansen was pondering the appearance under his microscope of the Mycobacterium leprae; in the Pacific, Father Damien was being drawn to his vocation on Molokai; from North India, Wellesley Cosby Bailey, a young Irish schoolmaster, came home to Dublin, having been confronted in his missionary work by the needs of neglected leprosy sufferers at Ambala, in the Punjab. His eloquent and passionate advocacy stimulated the first interest and financial support in Ireland for what was to become The Leprosy Mission, the oldest, and today still one of the largest, of the voluntary societies concerned with leprosy and the problems of those who suffer from it. 
In 1974, The Leprosy Mission celebrates its centenary as an international and interdenominational Christian society, with its headquarters in London and its auxiliaries in many parts of the world; its members continue to educate, stimulate and increase interest in the cause of those who suffer, and to care for them at every level of need. Today The Leprosy Mission looks back to solid pioneering achievements, beginning at a time when it was the only organization in the field, and looks forward to an increasingly effective future role in cooperation with others.

\section{Pioneer Contributions to the World of Leprosy}

Through the concern of its founder and his co-workers, a conscience and a consciousness about the needs of leprosy sufferers were established and rapidly expanded. To mitigate the appalling sufferings of untreated and unchecked leprosy, the Mission established asylums and financially supported others, first in India, then in Burma, China, and other parts of the world. Its work acted as a catalyst to more general action, and the Mission, besides establishing centres of its own, soon became known as the source of encouragement, advice and funds to others interested in leprosy relief. "Relief" was a fair description of its activities. With no armoury of drugs and little scientific knowledge, leprosy centres could offer only shelter, food, sympathy and a restoration of some human dignity to men and women ignored or rejected by their own communities. Attitudes often mirrored those of the contemporary Western society to the underprivileged, and some of the help offered was paternalistic, but it was nonetheless sincere and constructive.

The expansion of its leprosy centres, in number and size, was accompanied by an essential expansion of interest in its work among Christian communities throughout the world. Following its beginnings in Ireland, support was quickly given by individuals and church groups in England. Scotland and India. With little delay, they were followed by the USA (1877), Canada (1892), Australia (1900), New Zealand (1909), and Switzerland (1912), the last named a portent of the greater support which was to come from Europe in more recent times.

From its work in the United States of America grew American Leprosy Missions, Inc., now and for many years past an independent organization in its own right, with valued links of friendship and cooperation. During the early 1920's The Leprosy Mission gave its willing support and experience to help in the founding of the British Empire Leprosy Relief Association (BELRA, now LEPRA) and also encouraged the development of the French Committee of Help (which established the centre at Valbonne), the Taiwan Leprosy Relief Association and the Nippon Leprosy Mission.

The Mission was never complacent. In faith, its workers sought better methods of treatment. Its early literature contains many references to new remedies which, unfortunately, came to nothing; but consistently the Mission widened its knowledge and experience, aimed for higher standards of medical work, responded to new knowledge with changes of practice, and encouraged research.

With the widening use of sulphones in the early 1950's, the prevalent asylum-orientation gave way to the development of the Mission's centres as efficient long-term hospitals, with treatment leading to real hope of rehabilitation. The problems of rehabilitation stimulated Paul Brand-for long associated with The Leprosy Mission-and others, to develop the use of the technicues of plastic and orthopaedic surgery in remedying the deformities of leprosy sufferers. The 
Mission actively encouraged the training of its medical workers, as well as those of other societies, in reconstructive surgery, physiotherapy, and the prevention of deformity.

At the same time, under the stimulus of men like Muir and Cochrane, the Mission increasingly turned its attention to the untreated mass of patients beyond the walls of its hospitals. The development of pioneer S.E.T. (Survey, Education and Treatment) programmes was increasingly emphasized as the significance of early diagnosis and regular sulphone therapy was realized, both in controlling the disease in the patient and in limiting its spread through the community.

Since its earliest days, the Mission has stressed the value of the individual patient, rather than seeing them en masse. There were times in the development of control work when the Mission was criticized for moving too slowly, and thinking too small, by the advocates of mass distribution of dapsone. Now the Mission's emphasis is perhaps appreciated a little more, as experience shows that adequate case-holding depends on the development of the patient's confidence in his treatment, which in turn partly depends on the acknowledgement of his individual personality and response to his needs.

Training of national workers for responsibility has long been an important part of the work of the Mission. For many years medical scholarships have been granted to selected students, particularly in India. A number of senior leprologists can look back to such support in early days, and national leadership today far outweighs the still valued contribution of expatriates. Training has included conferences and workshops for many years. The activities of the Mission in this sphere go back to conferences of "Leper Asylum Superintendents" in the early years of the 20th century. Coupled with its training programme, the Mission has published technical and popular literature, both for leprosy workers, patients and supporters.

To promote further training and research the Mission, in full partnership with American Leprosy Missions Inc., financed, built, and still maintains the Schieffelin Leprosy Research Sanatorium in Karigiri, South India. In celebration of its 90th Anniversary, the Mission installed an electron microscope in the nearby Christian Medical College (CMC) Hospital, Vellore, for leprosy research purposes. Significant support is given to The Leprosy Study Centre, London, and the Mission is a founder member of ALERT, in Ethiopia.

As an international Mission, it has encouraged and supported efforts to draw together leprosy workers in closer cooperation. It was a founder member of the Federation of European Leprosy Associations (ELEP), is a long-standing supporter of the International Leprosy Association and its Journal, and took a leading part in the formation of the United Leprosy Aid Committee in Great Britain.

\section{The Future Rôle of The Leprosy Mission}

The Mission recognizes clearly that the ultimate responsibility for leprosy control measures lies with governments, which have both the right and the duty to co-ordinate and control all leprosy work within their jurisdiction: but it also recognizes the practical difficulties which in many areas make this a long-term hope, rather than a present reality.

The Mission continues then to have a role of significance. First, in continuing to share in the development of medical services to leprosy sufferers, in co-operation with governments and other voluntary agencies. This will include 
working within integrated medical facilities or separate services where appropriate. (It is of some interest that in 1973 the Mission's International General Council made an addition to its Constitution, empowering it to undertake general medical work, beyond the needs of leprosy sufferers, where this is necessary or desirable to meet the needs of the local community or to encourage the integration of leprosy treatment into general medicine.)

Secondly, in developing and maintaining a wide awareness of the needs of leprosy sufferers and acting as a voice to proclaim their right to health, social justice, freedom, and acceptance within the community.

Thirdly, in encouraging a diversified approach to the many problems of the disease of leprosy, and of its human victims.

Lastly, in demonstrating that Christian compassion and concern for the individual add a crucial dimension to the service of humanity. The Leprosy Mission is a Christian organization. It does not use its medical services as a tool for pressurized or indiscriminate evangelism, but believes that the effectiveness of modern treatment is increased when it is allied with a concern for the total personality of each patient, whose true happiness demands physical, mental, and spiritual fulfilment.

\title{
3. American Leprosy Missions, Inc.
}

\author{
OLIVER W. HASSELBLAD
}

President, 297 Park Avenue South, New York 10, U.S.A.

American Leprosy Missions (ALM) was established in 1906 as a committee of The Leprosy Mission. Its founder and chairman for 43 years was a prominent businessman and philanthropist, William Jay Schieffelin, and its membership was made up largely of Christian businessmen. Until 1917, when the Committee was separately incorporated, its sole function was to raise money for The Leprosy Mission to send to institutions in Asia, many of which had been established by American missionaries.

From the beginning, ALM's policy was that of an enabling, not a sending, agency nor an owner or administrator of institutions. In 1935, the General Secretary, William Mason Danner, made this policy clear in a letter granting funds for a hospital in Africa: "We wish it to be clearly understood that our responsibility begins and ends with this grant of funds."

While Dr Eugene R. Kellersberger was General Secretary from 1941 to 1954, a new dimension was added. Feeling that money given without any responsibility for its use did not ensure work of good quality, the Board of Directors drew up clearly defined priorities for the use of resources. And it required close direct contact with responsible administrators in the field in working out and agreeing upon objectives.

More than any other person. Dr Robert G. Cochrane. ALM's technical medical adviser from 1952 to 1965, laid the foundation for ALM's present policies. He 
was convinced that the rôle of a voluntary agency was to upgrade strategic institutions as a demonstration of the best methods of leprosy control, training, and research.

Earlier, while he was Principal of Vellore Christian Medical College in India, he and Dr Herbert Gass, Professor of Dermatology, together with leaders of The Leprosy Mission and American Leprosy Missions, developed the concept of such a demonstration centre in close proximity to a medical college. And in 1952, with Dr Gass as its first director, the Wm. Jay Schieffelin Leprosy Research Sanatorium was built at Karigiri, with a grant from ALM's Post War Fund. Here and at Vellore, Dr Paul W. Brand did his early pioneering work in surgical rehabilitation. Many significant contributions in leprosy research have come from the scientists at the Schieffelin centre, and its excellent training programme has included hundreds of workers in variows medical disciplines from all parts of the world.

Another important world centre for training and research arose from the vision of ALM's Dr Kellersberger back in the nineteen-forties. In a letter to the Ethiopian Ministry of Heal th he expressed the hope that the Princess Zenebework Hospital in Addis Ababa, built by American Leprosy Missions in 1933, "might well become not only a central leprosy hospital for the country, but also a training centre where doctors, nurses, teachers, public health workers would receive special training in social and clinical aspects of leprosy."

By 1965 this prophetic vision came to fruition with the establishment at the Princess Zenebework Hospital of the All Africa Leprosy Research and Training Centre (ALERT), with ALM as one of the five original sponsors. With the generous support of many other voluntary agencies, ALERT serves not only all African countries, but also serves internationally as an increasingly important demonstration, training, and research centre.

One of the most important aspects of American Leprosy Missions' training programme began in 1960 with the establishment of annual leprosy orientation seminars in cooperation with the United States Public Health Service (USPHS). Held every spring at the USPHS Hospital at Carville, Louisiana. these annual courses give a basic grounding in all aspects of the treatment and management of leprosy to medical personnel in all disciplines, both national and expatriate, Catholic and Protestant, who work or plan to work in countries where leprosy is a serious public health problem. Since the inauguration of the series more than 600 workers have attended the seminars, and many have been responsible for the improvement of existing programmes and the establishment of new ones in line with modern concepts of leprosy management.

In 1970 the ALM Leprosy Atelier was established by Dr Olaf K. Skinsnes with ALM funding. Located in the Department of Pathology of the University of Hawaii School of Medicine, it is equipped with an electron microscope and other facilities for advanced research. In July 1973 Dr Wayne M. Meyers was seconded by ALM as a Professor in the University of Hawaii to collaborate with Dr Skinsnes and other university medical scientists. The relationship to the University opens opportunity for training, as do projected developments in the management of leprosy in Hawaii.

Under development is the International Center for Training and Research on Leprosy and Related Diseases at Caracas, Venezuela, with the sponsorship of the Pan-American Health Organization. ALM has committed itself to financial support and participation on the Advisory Board of the Center.

The greatest share of American Leprosy Missions' resources are used for the 
delivery of health services to patients, individually and in the aggregate, with special consideration for the patient in relation to others and to the community. Support is also given to the movement towards integration of leprosy in to general health services, and to comprehensive community health planning which includes leprosy.

ALM's present priorities governing the use of its resources are based upon its nearly 70 years' experience. They are:

(1) Meeting individual needs as a continuing commitment. There is an equal commitment to help change programmes to conform with accepted principles of control and management.

(2) Assisting traditional custodial institutions to become centres of leprosy control.

(3) Providing training grants to medical workers in the necessary disciplines.

(4) Helping those programmes that are moving toward integration, whether at the level of general hospital or of the village dispensary.

(5) Developing pilot projects with social science and public health personnel, to help solve the serious problem of the tremendous numbers of severely dehabilitated patients, both within and outside institutions.

(6) Providing funds for new buildings and equipment in programmes that contribute to effective leprosy control.

(7) Providing consultative services of outstanding specialists to assist in the implementation of priorities.

(8) Responding positively to governmental and intergovernmental agency requests to develop leprosy control programmes.

American Leprosy Missions' support comes from individuals. churches, and church groups. It is not officially related to any sect or denomination. It maintains its inherent freedom $t$ act independently but in cooperation with other leprosy or related agencies.

\title{
4. Hind Kusht Nivaran Sangh (Indian Leprosy Association)
}

\author{
S. S. MAITRA
}

Honorary Secretary

The dawn of the twentieth century flashed a silver lining on the horizon for the dreaded, stigmatized and ostracized leprosy patient. Compassion had taken root in the hearts of men, though horror and prejudice were still slow to die. Father Damien had lit a torch. Colonel Bailey had trailed a luminous path. The formation of the British Empire Leprosy Relief Association (BELRA) had its ripples in India also. The Indian Council of BELRA was formed in the year 1925, with the Viceroy and Governor-General of India as its President, while Governors of Provinces and leading Indian Princes became its Vice-Presidents. The Indian 
Council concentrated its attention on (1) research; (2) training of medical men in the diagnosis and treatment of leprosy; and (3) propaganda. The Indian Council continued to do good work till 1950.

Independence brought about changes in the set-up of the Indian Council of BELRA also. In 1950, the Hind Kusht Nivaran Sangh (Indian Leprosy Association) was formed, taking over the assets and liabilities of the former organization. The important avowed objects of the Sangh are: the control of leprosy, relief to leprosy patients, and the eradication of leprosy in India. The Sangh endeavours to achieve these objects through health education programmes, and programmes of leprosy control and treatment. These programmes are initiated at the headquarters in New Delhi and implemented through its branches, which today are 16 in number. The State branches in turn organize district and local branches.

The Sangh has the President of India as its President. In order that concerted and co-ordinated efforts may be made in the direction of eradication of leprosy in India, the Sangh has a broad-based constitution, under which the Government, voluntary organizations, distinguished leprologists, medical scientists and social workers are brought together on one platform by giving them representation in the governing body of the Sangh.

As years rolled by, the Government and the voluntary organizations have increasingly involved themselves in the treatment of leprosy, and the Sangh gradually retreated from direct participation in these programmes. So, also, the Indian Council of Medical Research took over in 1956 the research work which until then had been conducted by the Sangh at the School of Tropical Medicine, Calcutta, with the cooperation of the Endowment Fund of the School and the Indian Council of Medical Research. Consequently, the Sangh began to concentrate on health education, rehabilitation of leprosy patients and publicity aimed at creating a national awareness of the problems of these patients, and ultimately the eradication of leprosy in India.

\section{Health Education}

An effective health education programme in leprosy should be aimed at the public at large, the medical profession, and the leprosy patients themselves. Real facts about leprosy have to be disseminated to the general public to dispel the age-old ignorance, horror and prejudice about the disease. Even today many medical practitioners not only keep themselves aloof from the treatment of leprosy but also place leprosy on a different footing from that of other diseases. Health education in leprosy, therefore, should strive to integrate the treatment of leprosy with general medical practice. So also, the leprosy patient needs encouragement and an awareness that the disease is curable.

This three-pronged approach to health education in leprosy is ably handled by the Sangh today, by means of posters, pamphlets and brochures. One of the first steps the Sangh took was to publish a set of 20 coloured wall posters in English, Hindi and some regional languages. These posters help to dispel old fears and prejudices about leprosy. As the old set became obsolete, new sets of posters were designed in consultation with the Central Health Education Bureau and were exhibited and popularized through the State branches. A selected set of these posters in English, Hindi and regional languages has been displayed in 2000 railway stations. 
Our pamphlets and booklets on the facts about leprosy written by leading leprologists are very popular both with the general public and the medical profession. The pamphlets are revised periodically, and new ones are added to the list from time to time.

\section{Leprosy in India}

The Sangh publishes in English a scientific quarterly journal, Leprosy in India, which is the official organ of the Sangh. Through this medium, we publish original articles, research reports, reviews, comments, abstracts from current literature, etc., which reflect the work done in the field of leprosy in India and in other countries. This journal is at present edited by Dr Dharmendra, an eminent leprologist of international standing.

\section{World Leprosy Day}

In India, World Leprosy Day is celebrated on the 30 January, to coincide with the day of the martyrdom of Mahatma Gandhi, who had an abiding interest in leprosy work. The Sangh organizes the celebration of this day in all parts of the country through its State branches, voluntary organizations, and Leprosy Control Units. The programmes for the celebration of Leprosy Day are directed towards the goal of health education and the raising of funds for leprosy work. Public meetings, processions, the sale of leprosy seals, essay and elocution competitions for school-children, and organizing of exhibitions are some of the activities in connection with the observance of the day.

\section{Rehabilitation}

Rehabilitation of leprosy patients is a task with which the Sangh is very much concerned. Rehabilitation is a process that should begin from the day the disease is diagnosed. The patient should be relieved of the mental strain that results from the shock to which he is exposed by the realization that he has contracted a dreaded disease. Also, he should not be allowed to develop any deformity by reason of carelessness and ignorance, and above all he should be returned to society as a self-reliant, self-respecting citizen, an asset to himself and to his fellow men. To this end, the Sangh conducts Physiotherapy Technicians' Training Courses to help para-medical workers to educate and train the patients. Refresher Courses are also conducted for trained physiotherapists to acquaint them with new knowledge on physiotherapy and to give them an opportunity to exchange experiences. In addition to this, the Sangh conducts Orientation Courses for medical practitioners engaged ir leprosy work, who in turn can thus give scientific guidance to trained physiotherapists.

\section{Shanti Illam}

In furtherance of the programme of rehabilitation, the Sangh maintains a home known as Shanti Illam at the Christian Medical College (CMC) and Hospital, Vellore. This home is intended for short-stay destitute leprosy patients undergoing pre- or post-operative treatment at the CMC Hospital. During the period 1968 to 1972,3140 leprosy patients were admitted to Shanti Illam, and a total of 
1766 operations were performed on them. During their stay at Shanti Illam, the patients are trained and encouraged to do some useful work, which not only serves as occupational therapy, but also helps them to learn a new trade which in turn encourages their self-reliance and also helps them to earn some money during their stay at the home.

\section{Scholarship and Awards}

The Sangh realizes that incentives should be provided to promising medical practitioners and research workers in leprosy, so that they may contribute their best in the very important task of eradicating leprosy in India. With this end in view, the Sangh has instituted a scholarship which will be awarded every alternate year to a medical graduate engaged in leprosy work for specialized training in leprosy at the Central Leprosy Teaching and Research Institute, Chingleput, for one year. The selected candidate receives Rs. 500 per month for the duration of his training. In the same way, the Sangh has instituted the Dr Keshab Chandra Sahu Memorial Gold Medal for the promotion of research into the causes and treatment of leprosy; the Medal is awarded once in every three years to a senior research scholar who has to his credit more than 10 years of outstanding work in leprosy.

\section{All-India Leprosy Workers' Conference}

From its inception in 1950, the Sangh took over the organization of the All-India Leprosy Workers' Conference. The first conference was held in 1947 at Wardha, with the blessings of Mahatma Gandhi, and continued to meet thereafter every two years. The central body of the Sangh is responsible for the policies and programmes of the conference, while the actual running of the conference is the responsibility of the State branch under whose auspices the conference is being held. These conferences have reflected the progress of leprosy work in India and have reviewed the working of leprosy programmes in the country. They have also been helpful in bringing together workers in the field of leprosy from the various parts of the country and to enrich these workers by pooling their knowledge and experience. This has helped to provide stimulus and inspiration to the workers and also guide-lines to administrators.

It is a happy augury that this year we are celebrating the Silver Jubilee of the Conference, together with the Centenary of Dr Armauer Hansen's discovery of the leprosy bacillus. The combined celebrations are being held at Sevagram with a 5-day seminar, which will be attended by leprologists and leprosy workers in India and to which invitations have also been extended to leprologists and leprosy institutions in other countries.

\section{Conclusion}

In the context of the expansion of leprosy work in India by the Government and by the increasing number of voluntary organizations, the rôle of the Hind Kusht Nivaran Singh has become selective. With its long tradition of pioneering service, it constantly seeks to explore the further unmet needs of patients and pass on the suggestions crystallized through its past experience to the Government and to the voluntary organizations. 
The Sangh's emphasis on health education and rehabilitation has paid rich dividends. Facts about leprosy are widely known today and the attitude of society, the medical profession, and the patients themselves has undergone vast changes in the right direction. The Sangh's rôle as a catalyst and co-ordinator in leprosy work is being increasingly accepted. Its essential function, namely, to promote the voluntary spirit, is receiving adequate attention. For, in the words of our late President, Dr Rajendra Prasad, "The quality of government work will rise in proportion to the growth of voluntary work.

\title{
5. The German Leprosy Relief Association
}

\author{
HERMANN KOBER and S. G. BROWNE
}

Although the German Leprosy Relief Association or Deutsches Aussïtzigen Hilfswerk (DAHW), was founded as recently as 1957, in the course of the last 16 years it has raised over 100 million D.M. (or over $£ 12$ million) for leprosy work, to be used mainly in Africa, Asia, and South America.

DAHW began almost by accident. Two young Germans, a theological student and a journalist, in the course of a visit to Ethiopia, called at an old-style leprosy centre (St Antoine, near Harrar) where a Dr Feron was trying almost single-handed to cope with an unbelievable amount of suffering due to leprosy. The two men saw the end-results of neglected leprosy, and were deeply affected. Back again in Würzburg, Germany, they spread the news and, together with their friends and a group of co-workers, began to collect money. They wanted to help; they wanted their friends to help. Thus was DAHW born.

At first, all its energies and efforts were bent towards assisting this one institution and this one doctor, but before a year was out cries for help reached them from other parts of Africa. At the same time, the response from the German population was unexpectedly eager. Thanks to articles in the press, the need was widely publicized, and money began to pour in.

Year by year, the financial response of the German people has increased pari passu with the requests for help. In 1958, 1.2 million D.M. was raised, and 5 centres abroad were helped; in 1964, the amount increased to 4 million D.M., and no fewer than 90 centres were helped. In 1972, the huge sum of 14 million D.M. was collected, which helped to support 180 centres. Among the contributors to DAHW we find businessmen who give generously, manual workers, and ordinary folk living on small fixed incomes. Youth groups raise money by staging theatrical plays, organizing football matches, etc. The mass media-radio, television and the press-have shown a great interest in DAHW and have been very generous in their coverage. Journalistic flair and professional connections have been harnessed to the task of disseminating information and arousing interest.

Up to the present, the funds collected have been used to support some 345 centres, schemes, and field projects in Africa (mainly Ethiopia, Uganda, Tanzania, Sierra Leone and Nigeria), a total of 147 projects in 29 countries; in Asia (especially India, Pakistan, Thailand and Korea), 160 in 18 countries; and in South America (Paraguay, Argentina, Brazil and Bolivia), 38 in 10 countries. About 600,000 leprosy patients in all have been helped in this way through these various projects of DAHW. 
Reviewing the past decade, it is possible to discern a gradual change in the way funds are allocated. At first, single centres and hospitals were supported, but the tendency now is to help subsidize field work and programmes in which leprosy is integrated into the general medical services, in accordance with the plans and ideals of the Ministries of Health of the various countries. Medical and social rehabilitation is by no means neglected.

DAHW assists training programmes in Addis Ababa, Caracas and Karigiri, channelling its support through staff, buildings and equipment. It also sponsors field workers, and has an impressive record in the comparatively short time of its existence - a total staff in the field of 145, comprising doctors, nurses, teachers, artisans, farmers and social workers. The large leprosy centre in Bisidimo near Harrar carries out extensive field work.

DAHW was one of the founder-members of ELEP, the Federation of European Anti-Leprosy Associations, and is a very active participant in the deliberations of its 16 member-associations. It works happily with other similar bodies in other continents, and also with the World Health Organization.

Although DAHW assists without distinction many religious bodies that are engaged in leprosy work, its basis is non-religious and non-sectarian; and although it cooperates with governments in their anti-leprosy campaigns, it is not a government institution. It has, however, links with the German Foreign Office and the Ministry of Economic Co-operation.

Conscious of the many serious gaps in our knowledge of leprosy, DAHW devotes a gratifying proportion of its resources to research, especially emphasizing the need for efficacious measures for preventing leprosy and for treating the disease as rapidly and completely as possible. DAHW helps to finance leprosy research at the Borstel Research Institute, and sponsored the International Symposium held in Borstel in 1970, the proceedings of which were published in a special fascicule of the International Joumal of Leprosy. Research activities at other centres are also assisted by DAHW, such as the work of Dr Tore Godal at the Armauer Hansen Research Institute, Addis Ababa. In addition. DAHW not only itself produces a fine range of literature, but subsidizes the publication of theses and makes a substantial grant to the International Joumal of Leprosy.

Last, but not least, mention must be made of the financial help given by DAHW for the work of Dr Eleanor Storrs on the armadillo at Indian Camp, Louisiana, an important project that has captured the imagination and opened the purse-strings of the outward-looking and forward-looking West Germans who, at ridiculously low cost and with such good effect, direct the affairs of the Deutsches Aussïtzigen Hilfswerk.

\title{
6. The Raoul Follereau Foundation
}

\author{
ANDRÉ RECIPON
}

President, 42 Rue Laugier, 75017 Paris, France

It was on 14 February 1968, that Raoul Follereau requested me (by a duly-attested declaration) to continue the "fight against leprosy and against all 'leprosies'" that he been waging for 40 years. Five years later is a kind of 
anniversary, an anniversary that provides an opportunity to take a look at the whole organization which. with the help of the many friends of Raoul Follereau throughout the world, I have brought into being to continue the work of one who is still called the "Vagabond of Charity".

In 1968, I began by forming the "Association of Raoul Follereau Foundations" to unite everybody and every Committee which in France and other countries responded to my appeal. It soon became necessary to make a distinction between the national organizations and the international grouping. It was thus that, in 1971, the "International Association of the Raoul Follereau Foundations" was established, with a Council of 3 members named by Raoul Follereau who, each in turn, assumes the rôle of President of the Association for one year. The 2 members (in addition to myself) are: The Reverend Father Corti, ex-President of the Amici dei Lebbrosi (Italy), and Monsieur René Henrion, the General Director of the Amis du Père Damien (Belgium)-the President for this year.

The principal national associations now linked in the International Association are organized in the following countries: France, Belgium, Italy, Luxembourg, Spain, Great Britain, Malta, Canada, Senegal, Mali, Ivory Coast, Upper Volta, Dahomey, Togo, Chad, Madagascar, Vietnam and Mauritius. All these national committees are responsible for organizating every year the World Leprosy Day, which was inaugurated in 1954 by Raoul Follereau, and whose 20th anniversary was observed on 28 January 1973, in over 125 countries. As its Founder hoped, this Day has become a significant focal-point for feelings of compassion towards the victims of leprosy, and it is by no means unknown in Africa on this Day for a Head of State to visit leprosy sufferers, thus showing by this act that these unfortunates are human beings just like the rest of us. Some of the national associations send doctors, nurses and nuns to the centres they support, but the greatest means of assistance adopted by the Raoul Follereau Foundations is by granting financial help to centres-both privately run and governmental-that are concerned with the campaign against leprosy.

I may be permitted in this connection to indicate that the best results hitherto achieved-in the Central African Republic, where $75 \%$ of leprosy patients have been discharged "disease arrested, or placed on observation without treatment", or in Upper Volta, where the figure is $60 \%$-are due to the close cooperation between the local Raoul Follereau Foundation and the respective Ministry of Health, and this in countries that are, incidentally, among the poorest in the world. Every year, the member-associations distribute for the care and rehabilitation of leprosy sufferers over 10 million French francs (the equivalent of nearly $£ 900,000$ ), which is the sum total of a multitude of gif ts from generous ordinary folk.

The Raoul Follereau Foundations, however, are not unmindful of their supreme objective, to wage "Raoul Follereau's struggle", which is really the "struggle against leprosy and against all the "leprosies" "-which are selfishness, meanness, indifference, and the rest-to upset the complacency of the well-off who, because they eat 3 times a day, imagine that the rest of the world does too; and to awaken in men's hearts that spark of love which will overcome self-centredness.

With these objects in mind, the Raoul Follereau Foundations have spread all over the world the writings and the message of Raoul Follereau, and in particular the "Small Book of Love" (Petit Livre d'Amour) in which we have brought together the main lines of thought from his books and his well-known lectures. 
We are proud that in the year 1973, when our Founder has celebrated his 70 th birthday, the circulation of this little book has reached 5 million copies in 22 languages. Copies, in the principal languages, may be obtained free of charge from: l'Association Française des Fondations Raoul Follereau, 42 rue Laugier, 75017 Paris, France.

\title{
7. ELEP-The European Federation of Anti-leprosy Associations
}

\author{
PIERRE VAN DEN WIJNGAERT \\ Founder of "l.es A mis du Père Damien" and (ieneral Secretary, ELEP. \\ 4 Rue Saint-Geoffroy, 4, F80 Amiens, France
}

Raoul Follereau, the Founder of World Leprosy Day, had for many years nurtured the hope that one day the various organizations having as their object the channelling of help for leprosy sufferers should present a united front within the framework of an international body. The Belgian association, "Les Amis du Père Damien", gave him the opportunity of fulfilling this wish when it organized in Brussels on 2 October, 1965, the first meeting of the European Associations engaged in the fight against leprosy. Raoul Follereau's idea met a real need, and less than a year later, on 25 September, 1966, the European Co-ordinating Committee of the Anti-Leprosy Associations came into being, adopting the name ELEP, signifying "Europe (E) against leprosy (LEP)". At last, on 19 April, 1969, in Paris, ELEP was constituted as The European Federation of Anti-Leprosy Associations, which obtained legal recognition in France on 25 October, 1971. Raoul Follereau was elected Honorary Life-President.

Today, ELEP brings together 20 national anti-leprosy associations, based in 14 Western countries-12 in Europe and 2 in North America. Its field of action extends to some 600 centres in 75 countries, and to over 900,000 leprosy patients. The total of financial help provided by the Member-Organizations of ELEP amounted in 1972 to U.S. \$7,237,996 (before devaluation) of which $\$ 3,135.791$ went to 33 African countries, and $\$ 2,923,916$ to 22 Asian countries; $\$ 534.045$ was shared between 16 countries of Latin America the Pacific Islands and Europe: and $\$ 452,217$ was devoted to research.

ELEP thus represents an important section of the voluntary agencies engaged in the world-wide anti-leprosy campaign. The internal resources of countries in which leprosy is a problem are quite inadequate. but they are helped in the organization of their anti-leprosy programmes by WHO, UNICEF, missionary societies, and numerous private agencies, national or foreign-based. Among the latter, ELEP is included; its Member-Organizations raise funds in countries not themselves facing a leprosy problem. These funds, accompanied by material in kind and sometimes by expatriate staff, are despatched to countries where leprosy constitutes a problem. Therein lies a fact almost unique, namely, aid offered by voluntary organizations in Western countries to assist in the fight against a disease that ravages the countries of the Third World. In the past, the heroic example of Father Damien and the no less remarkable example of Wellesley Bailey provided the inspiration; today we hear the voice of Raoul Follereau. 
The very multiplicity of these anti-leprosy associations, and the fact that their work lay overseas, made imperative some kind of union that would co-ordinate their activities and increase their usefulness, while at the same time safeguarding their individual interests by respecting their autonomy. Thus, ELEP has developed into an agency for co-ordination that brings together the Member-Organizations into a community of co-workers.

The Member-Organizations of ELEP are in essence working groups. The various aspects of the anti-leprosy programme-as much medical and scientific as social and humanitarian-are to be found among their activities. These range from eradication programmes to the maintenance of leprosaria, taking within their scope ambulatory treatment by mobile circuits, reconstructive surgery, physiotherapy, vocational therapy, manufacture of orthopaedic footwear, prosthesismaking, health education, and professional and social rehabilitation, as well as extending help to those victims of leprosy who are without resources, having been abandoned, or are suffering from irremediable deformities. On the other hand, members of ELEP have agreed to devote a sizeable proportion of their budget (over 5\%) to the financing of research projects. The training of staff in leprosy is also one of ELEP's priorities. The medico-social activities of ELEP thus differ distinctly from those of WHO, to which ELEP nevertheless may be regarded as complementary.

$\mathrm{n}$ order to assure the fullest cooperation between partners who are completely autonomous, ELEP is a co-ordinating body, which collects and collates information. The Office takes its cue in matters of general policy from the Medical Commission, and maintains close contact with Member-Organizations by regularly distributing such documents as the following:

(1) Applications for assistance from centres abroad, together with their Annual Reports; (2) a list of such centres, classified according to a decimal system by country and sometimes by province; (3) the Co-ordinated Budget, whose object is to avoid overlapping and to ensure a more equitable allocation of resources; and (4) an analytical summary of the diverse activities of all aided centres.

Contacts between the Member-Organizations of ELEP are constantly maintained, since their representatives have come to know each other and are now bound by strong ties of friendship. The working sessions held twice a year bring them together to discuss the budget, the aided projects and programmes, and to examine certain organizational and administrative problems. It is here that ideas for combined operations are developed, and temporary partnerships of Member-Organizations for specific projects are worked out. When several associations are helping a single centre, they may agree that one of the partners assumes the role of "co-ordinator". Under this title it undertakes to obtain all the necessary information about the activities of the centre so as to co-ordinate the financial help accorded, and to supervise the execution of the agreed programme, on behalf of the various partner-bodies and with their agreement. This system of co-ordination is sometimes extended to the whole of a country.

When a project includes an important programme, important in the sense of being financially costly, an appeal is sometimes made to Member-Organizations of ELEP to participate in financing a Joint Project. The overall responsibility of organizing and supervising this kind of project is entrusted to one of the participating partners. It was along these lines that the Dhamapuri Project, in Tamil Nadu (India), was financed by seven associations, one of which assumed the rôle of Co-ordinator. Some 40,000 leprosy patients live in the area of this Project. 
This co-ordination of the work of the Centres and the Joint Projects constitute a very definite success of the policy of ELEP.

The Medical Commission has for its major task the elaboration of the guide-lines of the antileprosy campaign, and thus to determine the common medical policy of ELEP Members. This policy constitutes the inspiration of all the co-ordinating activities of ELEP. The Commission comprises eminent leprologists and specialists with long experience of public health problems in tropical countries. The Commission examines certain important projects that are submitted to it by Member-Organizations, especially joint projects and research programmes. The Commisssion gives its advice in the light of the most recent medical and scientific knowledge of leprosy. From time to time it makes a study of the leprosy situation in a given country, and then gives its opinion on one or other aspect of the application of general principles, already enunciated and accepted, to the situation in question. Its members are invited to take part, as medical advisers, in all the meetings of ELEP. It is obvious that the Medical Co nmission plays a fundamental rôle within the heart of ELEP.

Thanks to the ever-increasing participation of the Member-Organizations in its activities, to the competence and judicious opinions expressed by its Medical Commission, and to the fund of information available through its Co-ordinating Office, ELEP is moving more and more towards a long-term planning of its activities, which today embrace practically one-third of those leprosy patients now under treatment throughout the world and which in the course of the next few years will exert an even greater impact on the world-wide campaign against leprosy. 